\title{
APLIKASI ABSENSI SISWA BERBASIS WEB \\ DENGAN DUKUNGAN SMS GATEWAY \\ PADA SMK KRIDAWISATA BANDAR LAMPUNG
}

\author{
Sukatmi ${ }^{1}$, Endah Septia Pitri ${ }^{2}$ \\ Dosen D3-Manajemen Informatika, AMIK Dian Cipta Cendikia Bandar Lampung \\ Jl. Cut Nyak Dien No. 65 Durian Payung (Palapa) Bandar Lampung \\ E-mail: sukatmi@dcc.ac.id, endah@gmail.com
}

\begin{abstract}
ABSTRAK
Presensi siswa di SMK Kridawisata masih di lakukan dengan cara manual. Bagian kesiswaan sering kesulitan apabila diminta keterangan tentang kehadiran siswa. Banyak orang tua/wali siswa yang mengeluh dikarenakan tidak mengetahui informasi kehadiran ataupun keterlambatan anaknya dari pihak sekolah. Perangkat komunikasi berupa telpon seluler atau handphone sudah bukan merupakan barang mewah lagi akan tetapi bisa dikatakan sebagai kebutuhan sekunder untuk setiap orang dikarenakan funsinya yang jauh lebih praktis serta efisien. Kemajuan teknologi tersebut dapat dimanfaatkan sebagai sistem pelaporan tentang informasi kesiswaan khususnya presensi. Saat ini masih banyak sekolah belum bisa memaksimalkan teknologi tersebut setidaknya untuk memantau anak dari mana saja tanpa harus pergi ke sekolah hanya untuk menanyakan kehadiran anaknya.
\end{abstract}

Mengingat pentingnya tingkat kehadiran siswa disekolah maka perlu dibuat suatu system yang dapat melalukan control terhadap kehadiran komponen-komponen sekolah tersebut. Oleh karena itu dalam penelitian yang berjudul "Aplikasi Absensi Berbasis Web Dengan Dukungan SMSGateway Pada SMK Kridawisata" ini akan dibuat untuk system presensi sekolah dengan dukungan teknologi SMS untuk membantu dalam mencatat data kehadiran siswa. Degan adanya system ini diharapkan mampu meningkatkan kedisiplinan siswa di sekolah.

Database dirancang untuk menyimpan data presensi siswa sesuai dengan kebutuhan SMK Kridawisata. Aplikasi absensi siswa ini merupakan aplikasi berbasis web dengan bahasa pemrograman php, database MySQL, dan dilengkapi dengan dukungan SMSGateway untuk memberikan informasi kepada orang tua/wali murid. Keluaran dari aplikasi ini adalah rekapitulasi absensi siswa per hari, per bulan, dan per semester yang digunakan untuk pelaporan kehadiran siswa.

Kata Kunci: aplikasi, absensi, web, MySQL, SMS Gateway 


\section{ABSTRACT}

Presensi numbers of students in vocational high schools kridawisata still in do with manual way. The student often distressed when information about school participation. Many parents or wali students who complain because do not know information or delay the presence of his son from the schools. Communications device of cellular phone or cell phone it is of is luxury goods will be but it can be said as the needs of secondary to everyone because funsinya who far more practical and efficient. Progress the technology can be used as a reporting system for information especially presensi student. At the present time there were still many schools has not been able to make every effort to ensure to the technology of such at least to monitor the son of from anywhere as it without have to go to school only to ask questions about the presence of his son.

Given the importance of attendance at the school students needs to be made a system which can hold control of the presence of komponen-komponen the school. Hence the study called "web based applications for a vocational school in kridawisata smsgateway" presensi to systems will be built with the support of the school system technology to aid in record the data of the students. In the system is expected to increase discipline students in a school. In the presence of system patients outside the system is expected to increase the discipline of students in a school.

Databases designed to store data presensi kridawisata vocational students in accordance with their needs. Application absentee students is based program web by programming language php, mysql database, And equipped with the support of the smsgateway to provide us with information to parents who do not / guardian over his pupil. Output of this program is of the turnout number of the recapitulation of the students per day, per month, And per semester used to reporting school participation.

Password: application, absentee, web, mysql, sms gateway 
ISSN 2337-8344

\section{PENDAHULUAN}

Era globalisasi merupakan realita yang harus di hadapi oleh semua orang, di mana kita dituntut untuk bergerak cepat pada semua aktifitas. Begitu juga dengan sebuah layanan pendidikan, instansi pemerintah atau badan usaha. Dengan adanya sebuah sistem yang terkomputerisasi diharapkan akan memberikan kemudahan untuk mendapatkan informasi yang cepat dan akurat. Keberhasilan dalam sebuah organisasi ataupun instansi tak pernah lepaskan dari kedisplinan semua steakholder yang ada. Di sekolah kedisplinan kehadiran dari siswa merupakan hal yang terpenting untuk kesuksesan kegiatan pembelajaran. Di SMK Kridawisata presensi siswa masih di lakukan dengan cara manual. Bagian kesiswaan sering kesulitan apabila diminta keterangan tentang kehadiran siswa. Banyak orang tua/wali siswa yang mengeluh dikarenakan tidak mengetahui informasi kehadiran dan keterlambatan anaknya dari pihak sekolah. Perangkat komunikasi berupa telpon seluler atau handphone sudah bukan merupakan barang mewah lagi akan tetapi bisa dikatakan sebagai kebutuhan sekunder untuk setiap orang dikarenakan funsinya yang jauh lebih praktis serta efisien bila di bandingkan dengan telpon rumah, dengan adaanya kemajuan teknologi tersebut seharusnya tiap sekolah sudah mempunyai aplikasi untuk membuat sistem pelaporan tentang informasi kesiswaan khususnya presentasi. Saat ini masih banyak sekolah belum bisa memaksimalkan teknologi tersebut setidaknya untuk memantau anak dari mana saja tanpa harus pergi ke sekolah hanya untuk menanyakan kehadiran anaknya.
Mengingat pentingnya tingkat kehadiran siswa disekolah maka perlu dibuat suatu system yang dapat melalukan control terhadap kehadiran siswa sekolah tersebut. Salah satu sarana untuk kepentingan tersebut adalah perlu daibangun dan diterapkan Aplikasi Absensi Berbasis Web Dengan Dukungan SMS Gateway.

Tujuan dibuatnya aplikasi presensi siswa adalah untuk menyediakan database presensi siswa sesuai dengan kebutuhan SMK Kridawisata dan membantu pengolahan data presensi siswa sehingga mampu menyediakan laporan kehadiran siswa secara harian, bulanan, dan per semester.

\section{METODE PENELITIAN}

Penelitian ini termasuk ke dalam penelitian Research and Development (R\&D). Research and Development ( $R$ \& D) merupakan suatu proses atau langkah-langkah untuk mengembangkan suatu produk baru atau menyempurnakan produk yang telah ada yang dapat dipertanggungjawabkan. Adapun metode pengembangan sistem yang digunakan adalah Extreme Programming (XP). Alur penelitian pengambangan aplikasi absensi siswa berbasis web dengan dukungan SMS Gateway dapat dilihat pada gambar 1 berikut 


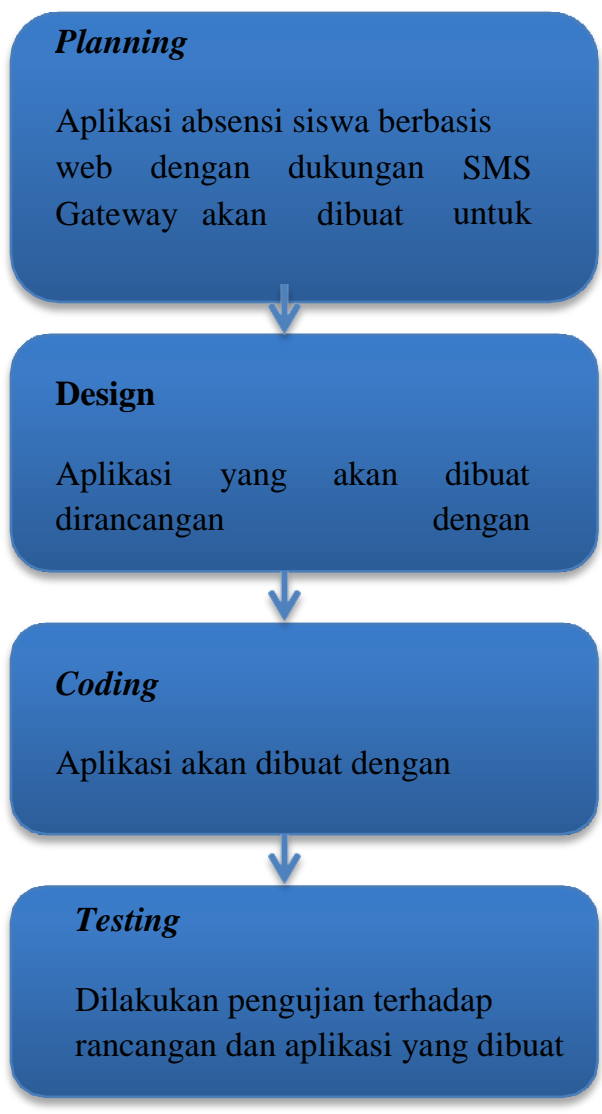

Gambar 1. Alur Penelitian Pengembangan Aplikasi Absensi Siswa Berbasis Android dengan

Dukungan SMS Gateway

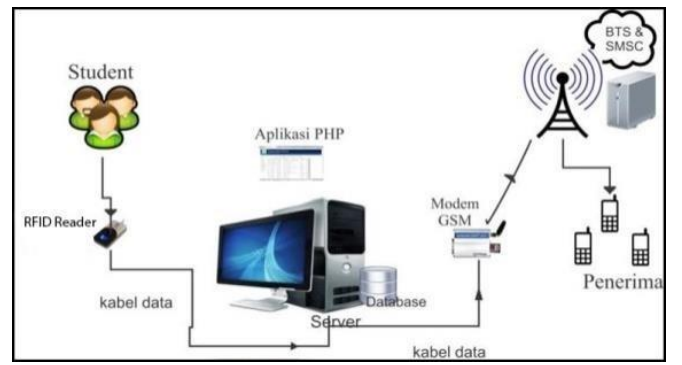

Gambar 2. Cara Kerja SMS Gateway

\section{LANDASAN TEORI}

\section{Aplikasi}

Pengertian Aplikasi Menurut Kamus Kamus Besar Bahasa Indonesia (KBBI) adalah penerapan dari rancang sistem untuk mengolah data yang menggunakan aturan atau ketentuan bahasa pemrograman tertentu. Aplikasi adalah suatu program komputer yang dibuat untuk mengerjakan dan melaksanakan tugas khusus dari user (pengguna). Menurut Rachmad Hakim S (2012:38) aplikasi adalah perangkat lunak yang digunakan untuk tujuan tertentu, seperti mengolah dokumen, mengatur Windows \&, permainan (game) dan sebagainya.

\section{Presensi}

Berdasarkan kamus Bahasa Indonesia, Absensi adalah tidak bekerjanya seorang pegawai pada saat hari kerja, karena sakit, izin, alpa atau cuti. Presensi adalah daftar administrasi ketidakhadiran pegawai. Dimana pegawai yang tidak hadir akan tercatat di daftar abensi kepegawaian dan kapan saja bisaa di cek oleh atasan perusahaan

\section{SMS Gateway}

Salah satu media komunikasi yang cukup diminati ialah pesan singkat (SMS). Agar SMS tersebut dapat terhubung dengan database, maka perlu dibangun sebuah system yang disebut SMS Gateway. Istilah gateway dapat diartikan sebagai pintu gerbang bagi penyebaran informasi. Dalam dunia komputer gateway dapat diartikan sebagai jembatan penghubung antara 
satu sistem dengan sistem yang lain. Dalam artian luas SMS Gateway adalah sebuah aplikasi yang merubah proses SMS dari Mobile-Equipment ke PC/Laptop, SMS Seperti layaknya fitur di telepon selular, tetapi ada perbedaan dari segi fitur, dan fungsi yang bisa dibuat berdasarkan kebutuhan bisnis. Dengan adanya software SMS Gateway dapat mengatur SMS lewat PC atau laptop dengan mudah dan cepat. Seperti mengatur kontak dengan menggunakan Excel atau notepad, mengatur SMS keluar, mengirim SMS perkelompok, mengirim SMS khuusus pelanggan, membuat SMS dengan jawaban otomatis yang bisa diatur isi SMS nya.

\section{Extreme Programming (XP)}

Paradigma pembangunan mencakup seperangkat aturan dan praktik yang terjadi dalam konteks kerangka empat kegiatan yaitu: perencanaan, desain, coding, dan pengujian. Keempat aktivitas inilah yang akan menghasilkan sebuah perangkat lunak yang didasari dengan konsep model Extreme Programming. (Pressman: 2010: 73).

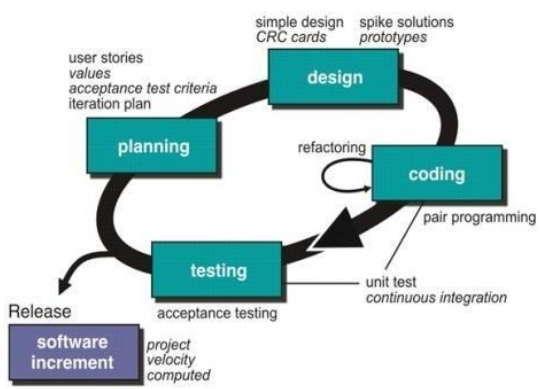

Gambar 3. Kerangka Kerja Extreme Programming

\section{Use Case Diagram}

Diagram use case adalah diagram yang menunjukkan fungsionalitas suatu sistem atau kelas dan bagaimana sistem tersebut berinteraksi dengan dunia luar, dan menjelaskan sistem secara fungsional yang terlihat user. Biasanya dibuat pada awal pengembangan. Use case diagram menggambarkan fungsionalitas yang diharapkan dari sebuah sistem. Yang ditekankan adalah "apa" yang diperbuat sistem, dan bukan "bagaimana". Sebuah use case merepresentasikan sebuah interaksi antara aktor dengan sistem.

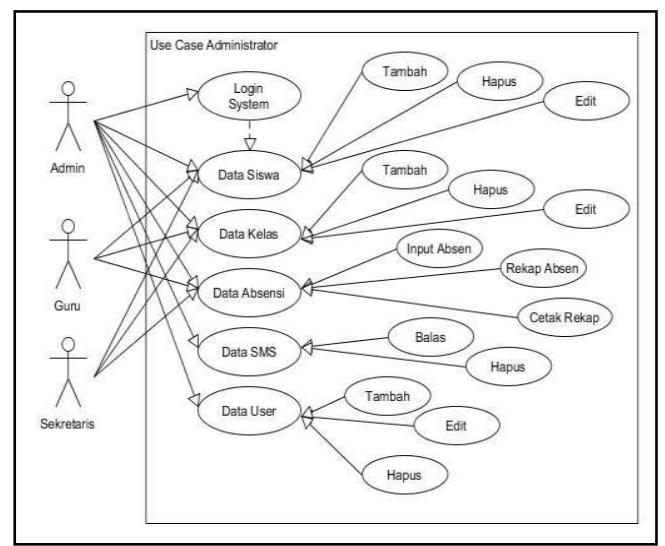

Gambar 4. Use Case Diagram Aplikasi Absensi Berbasis Android

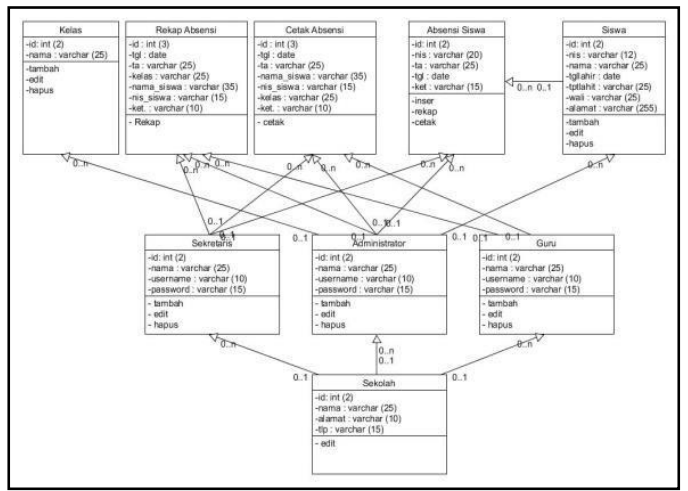

Gambar 4. Use Case Diagram Aplikasi Absensi Berbasis Android 


\begin{abstract}
Class Diagram
Kelas diagram adalah sebuah simbol kelas yang digunakan untuk memberikan batasan atau penanda bagaimana kelas lain menggunakan attribut, constructor dan method dari sebuah kelas, pada kelas diagram itu terdiri dari beberapa nama symbol.
\end{abstract}

\section{Activity Diagram}

Activity Diagram adalah diagram yang menggambarkan workflow (aliran kerja) atau aktivitas dari sebuah sistem atau proses bisnis. Yang perlu diperhatikan adalah bahwa diagram aktivitas menggambarkan aktivitas sistem bukan apa yang dilakukan aktor, jadi aktivitas yang dapat dilakukan oleh sistem.

\section{PHP}

PHP merupakan singkatan dari PHP Hypertext Preprocessor. PHP merupakan bahasa pemrograman skrip yang diletakkan dalam server yang biasa digunakan untuk membuat aplikasi web yang bersifat dinamis. Maksud web dinamis adalah dapat membentuk suatu tampilan web berdasarkan permintaan terkini, dapat dilakukan dengan menampilkan isi database ke halaman web. PHP juga digunakan secara command line, yaitu skrip PHP dapat dijalankan tanpa melibatkan web server maupun browser (Kadir, 2008:51).

\section{MySQL}

MySQL (My Structure Query Languange) adalah salah satu jenis database server yang sangat terkenal dan banyak digunakan untuk membangun aplikasi web yang menggunakan database sebagai sumber dan pengelolaan datanya. Mysql bersifat open source dan menggunakan SQL (Structured Query Languange). MySQL biasa dijalankan diberbagai platform misalnya windows Linux, dan lain sebagainya.

\section{HASIL DAN PEMBAHASAN}

\section{RANCANGAN SISTEM}

\section{Use Case Diagram}

Use case diagram merupakan interaksi antara user dengan sistem. Interkasi antara user dengan aplikasi absensi berbasis web dengan dukungan SMS Gateway dapat di ilustrasikan dengan use case diagram pada gambar 4 berikut.

\section{Activity Diagram}

Activity Diagram adalah diagram yang menggambarkan worlflow (aliran kerja) atau aktivitas dari sebuah sistem atau proses bisnis. Aliran kerja untuk aplikasi absensi siswa berbasis android dengan dukungan SMs Gateway dapat dilihat pada activity diagram berikut. 


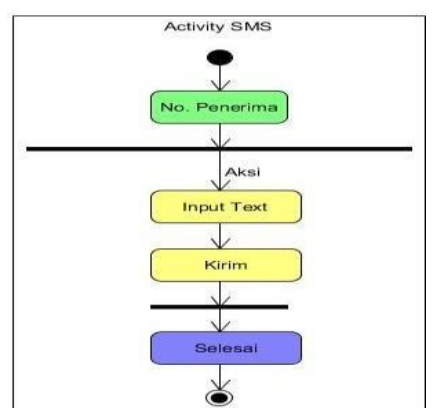

Gambar 5. Activity diagram untuk user

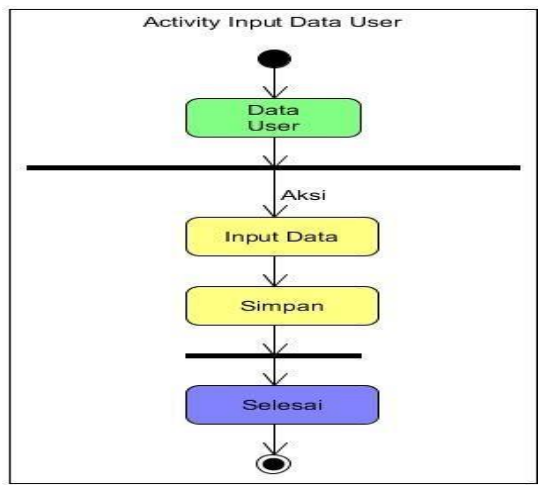

Gambar 6. Activity diagram untuk SMS Gateway

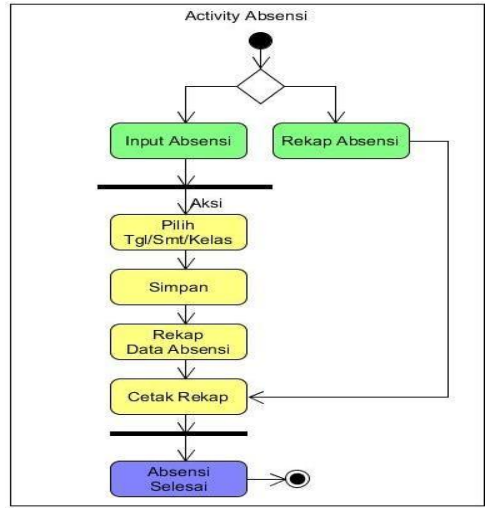

Gambar 7. Activity diagram untuk Absensi

\section{Class Diagram}

Class diagram adalah model statis yang menggambarkan struktur dan depenelitian class serta hubungannya antara class. Class diagram untuk aplikasi absensi siswa berbasis android dengan dukungan SMs Gateway dapat dilihat pada gambar berikut.

\section{Hasil Program}

Pada aplikasi ini tersedia fitur-fitur untuk keperluan pendataan absensi siswa diantaranya data siswa, data kelas, data user, sms gateway, absensi, dan laporan absensi. Fitur-fitur tersebut di uji sesuai dengan fungsi yang telah di rencanakan.

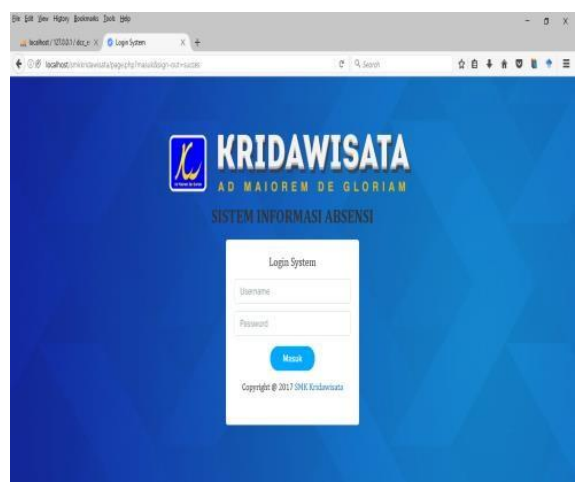

Gambar 9. Form Login

Untuk memulai menggunakan aplikasi ini user harus login ke system terlebih dahulu dengan username dan password yang telah di tambahkan oleh administrator. Setelah memasukkan username dan password maka system akan melalukan pemeriksaan di database berdasakan username dan password yang telah di masukkan. Apabila 
ISSN 2337-8344

ditemukan username dan password selanjutnya akan masuk ke halaman utama sesuai dengan level user

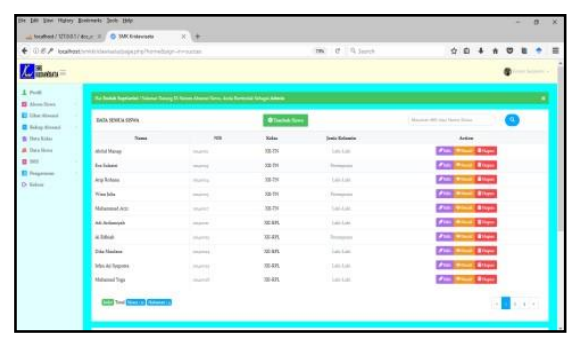

Gambar 10. Halaman Utama Aplikasi

Setelah login berhasil selanjutnya user akam masuk ke halaman utama asplikasi. Halaman utama aplikasi menampilakn data siswa dan data kelas dan menu-menu yang dapat di gunakan user untuk mengelola data.

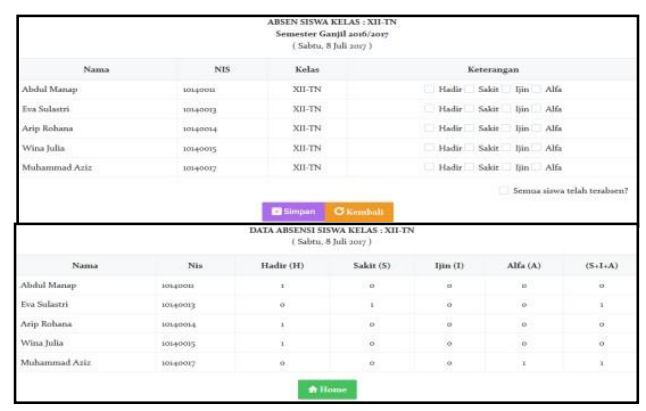

Gambar 11. Form Absensi

Penginputan absensi siswa dapat dilakukan oleh user admin dan sekretaris dengan memilih menu absensi pada system. Sebelum melakukan absensi terlebih dahulu memerika semester yang aktif pada tahun ajaran yang sedang berjalan. Semester yang aktif akan digunakan sebagai pengelompokan data absensi sesuai dengan semester yang berjalan. Apabila sudah sesuai selanjutnya memilih kelas yang akan di absen dan mencentang seluruh siswa berdasarkan keterangan (hadir, sakit, izin, atau alfa) kemudian klik button "Simpan". Jika input absensi berhasil selanjutnya akan menuju ke halaman data absensi yang telah di input dengan menampilkan status absensi siswa.

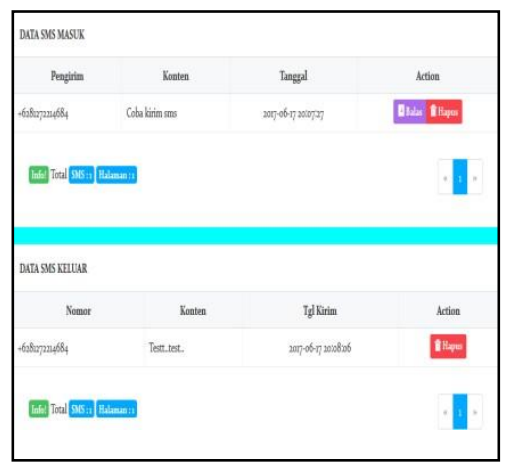

Gambar 12. Form SMS Gateway

SMS Gateway adalah fasilitas SMS dengan kartu GSM yang di tambahkan ke dalam aplikasi ini. Setiap proses

absensi selesai maka secara otomatis aplikasi akan mengirimkan sms dengan keterangan kehadiran siswa kepada orang tua/wali masing-masing. Dengan adanya system ini maka orang tua/wali murid dapat mengetahui kedisiplinan anak-anaknya. Selain pengiriman secara otomatis, admin juga dapat mengirimkan sms secara manual ke nomor-nomor tertentu dengan menggunakan form kirim sms yang di sediakan pada aplikasi. Form pengiriman sms seperti pada gambar di bawah ini: 


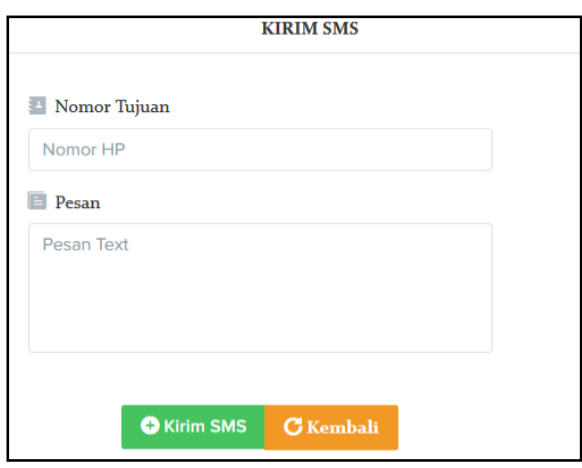

Gambar 13. Form Kirim SMS

SMS otomatis pada proses absensi siswa dapat di matikan dan di hidupkan dengan menggunakan pengaturan pada halaman edit sms otomatis. Form pengaturan sms seperti pada gambar di bawah ini:

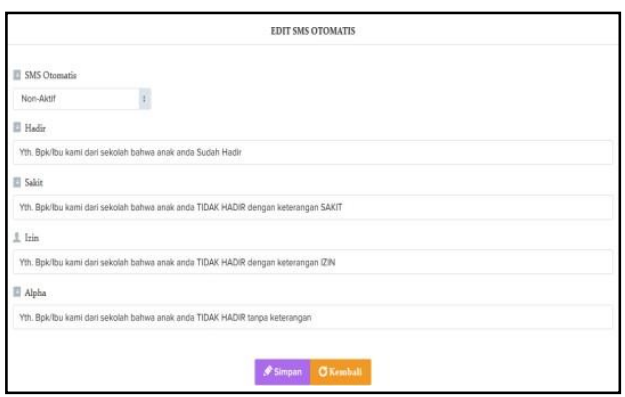

\section{Gambar 14. Form Notifikasi SMS}

Rekap absensi terdiri dari tiga jenis yaitu rekap harian, rekap periode, dan rekap per semester. Untuk menampilkan rekapitulasi per hari terlebih dahulu memilih tanggal kemudian kelas, selanjutkan klik button "Rekap". Tabel dibawah rekapitulasi akan muncul data absensi sesuai dengan yang telah dipilih. Form rekapitulasi absensi seperti pada gambar di bawah ini:

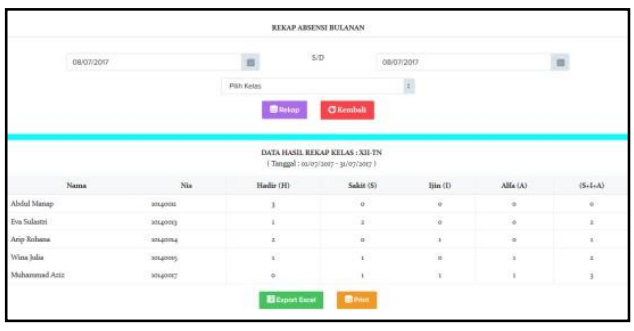

Gambar 15. Form Rekap Absen Harian

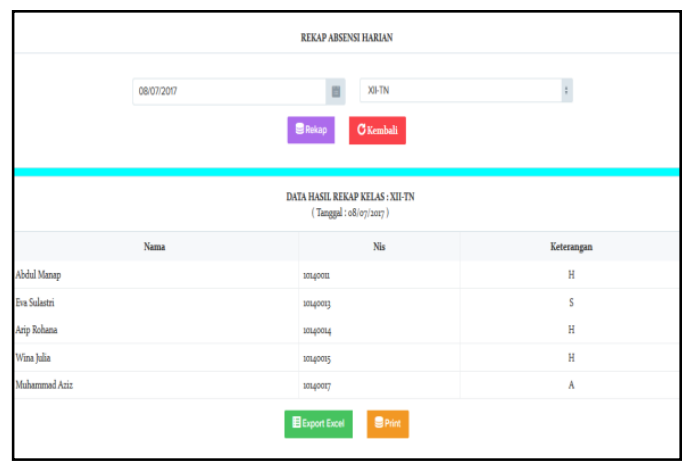

Gambar 16. Form Rekap Absen Periode Bulanan

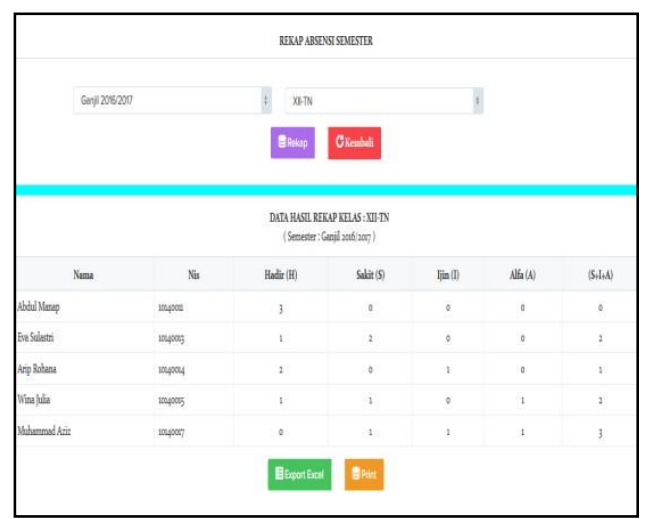

Gambar 17. Form Rekap Absen Per Semester 


\section{KESIMPULAN}

Database yang dirancang di gunakan untuk menyimpan data presensi siswa sesuai dengan kebutuhan SMK Kridawisata. Aplikasi absensi siswa yang di rancangan merupakan aplikasi berbasis web dengan bahasa pemrograman php, databae MySQL, dan dilengkapi dengan dukungan SMS Gateway untuk memberikan informasi kepada wali murid, bagian kesiswaan ataupun pihak pengguna lainnya. Keluaran aplikasi adalah rekapitulasi absensi siswa per hari, per bulan, dan per semester yang digunakan untuk pelaporan kehadiran siswa.

\section{DAFTAR PUSTAKA}

Abdul Kadir, 2008. Dasar Pemrograman Web Dinamis Menggunakan PHP. Yogyakarta: Andi Offset.

Bunafit Nugroho, 2004, Aplikasi Pemrograman Web Dinamis dengan PHP dan MySQL, Gava Media, Yogyakarta.

Jogianto H.M., 2005, Analisis Dan Desain (Sistem Informasi : Pemdekatan Terstruktur Teori Dan Praktek Aplikasi Bisnis. Yogyakarta : Andi Offset, Edisi Ketiga.

Rahmad Hakim S, 2012. Pengantar Sistem Informasi Bisnis. Jakarta: Elex Media Komputindo.

Rozidi, Romzi Imron. 2004. Membuat Sendiri SMS Gateway (ESME) Berbasis Protokol SMPP. Penerbit Andi. Yogyakarta.
R.S. Pressman, 2010, Software Engineering : a practitioner's approach (Rekayasa Perangkat Lunak: Pendekatan seorang praktisi), McGraw-Hill, New York.

Sugiarti, Yuni. 2013. Analisis dan Perancangan UML (Unified. Modeling Languege). Yogyakarta: Graha Ilmu. 
JURnal InformaSI dan KomPUTer

Volume 6 Nomor 1 2018 